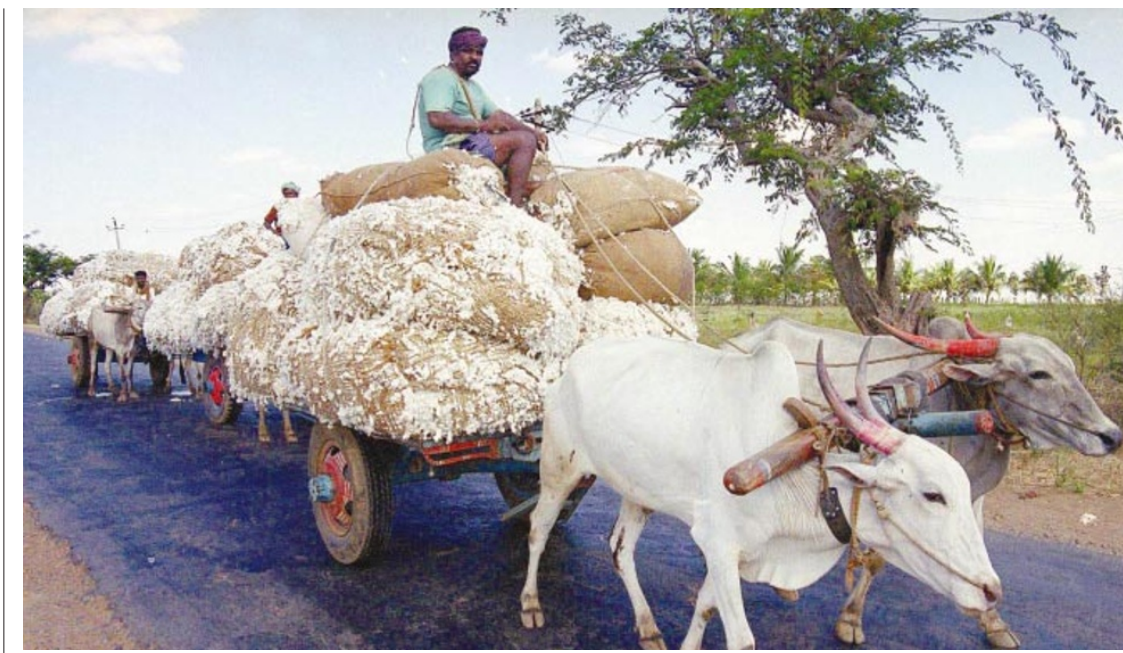

Road to ruin or road to riches? Indian farmers taking their cotton crop to market last month.

\title{
India debates results of its first transgenic cotton crop
}

\section{K. S. Jayaraman, New Delhi}

India has just collected its first commercial harvest of transgenic cotton. But even as the last bolls were being picked, arguments were beginning over the crop's success.

About 50,000 farmers planted transgenic cotton in India last year, after the government licensed commercial use of the crop in March. The plants carry a gene for producing a toxin from the bacterium Bacillus thuringiensis $(B t)$, making them resistant to the bollworm caterpillars that ruin up to half the crop each year.

Assessments are being muddied by the lack of a large-scale, independent survey. The season was hailed as a success by the company that sells the seeds, Mahyco Monsanto Biotech (MMB) - a joint venture between Maharashtra Hybrid Seed Company in Jalna and Monsanto in St Louis, Missouri. Yields were up and pesticide use down, the firm claims. Environmental groups, on the other hand, report the opposite effects.

An analysis of the field trials that preceded the licensing indicates that transgenic cotton may benefit Indian agriculture, however. Agricultural economists Matin Qaim of the University of Bonn in Germany and David Zilberman of the University of California, Berkeley, examined controlled trials of $B t$ cotton grown in 157 farms across three Indian states. Their results, published last week (M. Qaim and D. Zilberman, Science 299, 900-902; 2003), show that transgenic varieties gave $80 \%$ higher yields and allowed farmers to cut pesticide use by $70 \%$ compared with normal cotton. "The farmers were very positive," says Qaim.

$B t$ cotton reduces total cost when there is a heavy bollworm infestation, says
Ebrahimali Abubacker Siddiq, former deputy director of crop science at the Indian Council of Agricultural Research, and chair of the committee that monitored the trials and the commercial planting. But he points out that the government's analysis of the 2001 trial puts the increase in yield at $20-60 \%$. "Claiming increased yields of $80 \%$ will raise farmers' expectations," he cautions.

A number of issues remain to be resolved, warn researchers, including the possibility that bollworms may develop resistance to the insecticide produced by the plants. The government requires farmers using $B t$ cotton to grow ordinary cotton on $20 \%$ of their land to delay the spread of resistance. But Devinder Sharma of the Forum for Biotechnology and Food Security, an environmental group based in New Delhi, says that many farmers failed to comply with this condition.

Absence of a mechanism to assess longterm effects is another problem, adds Siddiq. "Hardly anything is known about how long the leftover biomass of transgenic crops would remain in the soil and what kind of environmental impact it would have," he says.

Such issues are being studied by groups on all sides of the debate, while state governments and agricultural researchers push to introduce more transgenic crops to India. Insect-resistant varieties of rice, chickpea and a pulse called pigeon pea are awaiting large-scale trials. The department of agriculture in Andhra Pradesh is hoping to introduce insect-resistant varieties of sorghum and peanuts within two years. In December the National Academy of Agricultural Sciences endorsed the introduction of salttolerant rice, now undergoing trials. Additional reporting by John Whitfield, London.

\section{Social scientists call for abolition of dishonesty committee}

\section{Alison Abbott}

Following its controversial ruling on political scientist Bjørn Lomborg's book The Skeptical Environmentalist, the Danish Committees on Scientific Dishonesty (DCSD) is now the subject of debate itself.

The DCSD has quietly ruled on an average of one case of alleged misconduct per year since it was established in 1992. But many researchers felt it overstepped the mark by investigating Lomborg's book, which paints an unusually rosy picture of the global environment.

In a report published on 6 January, the DCSD said that the book was "objectively speaking, deemed to fall within the concept of scientific dishonesty" (see Nature 421, 195 \& 201; 2003). The decision triggered debate in the Danish parliament and newspapers. Last week science minister Helge Sander asked the Danish Research Agency to set up an independent working group to examine the regulatory basis and procedures of the DCSD.

The affair has split Denmark's academic communities. Given Lomborg's background, many social scientists think that his book should not be judged by criteria used to assess dishonesty in the natural and medical sciences.

Jørn Henrik Petersen, a social historian at the University of Southern Denmark in Odense, says that selection of information to develop a theory anathema to natural scientists - is an integral part of many social sciences. "It is out of the question to argue that any selection can be completely objective," he says. Petersen is one of many social scientists who say that the DCSD should be disbanded.

Some 600 natural and medical scientists in Denmark have signed a petition in support of the DCSD that has been presented to the Danish Research Agency. "We don't object to the procedures being re-examined, but it is expedient for any society to have this kind of committee," says Jens Rehfeld, a health researcher at the Rigshospitalet in Copenhagen.

The working group, including social and natural scientists and journalists, will be chaired by Mogens Pedersen, a political scientist at the University of Southern Denmark. Key issues will be whether the definition of 'scientific dishonesty' should be changed, what kinds of work should be included in the DCSD's remit, and how the results of any deliberation should be presented to the public. It is expected to report before the summer. 